\title{
Building cooperative capacity: the specialty coffee sector in Nicaragua
}

\author{
Nigel Poole \\ Centre for Development, Environment and Policy, \\ School of Oriental and African Studies (SOAS), University of London, \\ London, UK, and \\ Jason Donovan \\ World Agroforestry Centre, Lima, Peru
}

\begin{abstract}
Purpose - Within the context of widespread donor support for producer organizations, the purpose of this paper is to examine the impact of interventions aimed at rescuing a failed cooperative and improving performance and business linkages between grower-suppliers and international markets through enterprise development.

Design/methodology/approach - The paper reports a case study of a Nicaraguan coffee cooperative, Soppexcca, which received substantial donor support at the time of the international coffee crisis between 1999 and 2004. The study used a framework of organizational structure, strategy, empowerment, and performance to assess business performance and sustainability. Quantitative and qualitative data collection focussed on asset building and changes during the period 2005-2009.

Findings - Soppexcca achieved major advances in asset building. External interventions played a pivotal role in building organizational capacity to respond to buyers' demands and market-related shocks. Support was received not only from donors but also from supply chain partners and thirdsector organizations. However, important gaps remain, and addressing these gaps requires changes in Soppexcca and sustained support.

Research limitations/implications - As a case study, findings cannot be readily generalized but the implications will be of significance beyond the coffee sector in Nicaragua, wherever and in whatever sector building cooperative capacity is an important development objective.

Social implications - Experience with Soppexcca shows that the creation of sustainable collective organizations is a long-term process, particularly in respect of building human capital.

Originality/value - The paper examines enterprise development using concepts of capital asset formation and cooperative performance, and argues the significance of effective links between value chain stakeholders as well as internal cooperative performance.
\end{abstract}

Keywords Nicaragua, Asset building, Business development, Co-operative organizations, Coffee, Development policy, Supply chain linkages

Paper type Research paper

(C) Nigel Poole and Jason Donovan. Published by Emerald Group Publishing Limited. This paper is published under the Creative Commons Attribution (CC BY 3.0) licence. Anyone may reproduce, distribute, translate, and create derivative works of this paper (for both commercial and non-commercial purposes), subject to full attribution to the original publication and authors. The full terms of this licence may be seen at http://creativecommons.org/licences/by/3.0/legalcode.

This study was made possible by grants from the Ford Foundation, implemented by the Tropical Agricultural Research and Higher Education Center (CATIE), Costa Rica. Ingrid Herrera and Rafael Vallecillos provided valuable assistance with data collection. The authors owe a special thank to the cooperative Soppexcca and the Central America office of Lutheran World Relief for facilitating data collection.

\section{Building cooperative capacity}


JADEE

4,2

134

\section{Introduction}

Following considerable debate on market-oriented development approaches such as business development services and making markets work for the poor, researchers and development practitioners have shown growing interest in supporting new or improved value chain links between smallholders and other market actors (Humphrey and Navas-Alemán, 2010; Stoian et al., 2012). Market-oriented development for addressing poverty reduction responds to the need to re-invigorate rural development through, among other things, increased income and a decent standard of living for people in developing and emerging economies (World Bank, 2007). Rapid growth in demand for agrifood products in which smallholders are considered to have a comparative advantage, such as fresh produce and specialty coffee that require extensive labor inputs, creates significant opportunities for market-oriented development. Success in demanding agrifood markets requires smallholders and small businesses to meet high specifications for delivery, volume, and quality, including food safety standards, as well as maintain strong links with processors and other chain actors further downstream.

Development interventions can play an important role in facilitating smallholders' and small businesses' ability to participate in these markets (Webber and Labaste, 2010). Intervention design will vary according to the local context as well as the particular interests of funding and implementing organizations (Poole et al., 2013). Some interventions will target privately owned businesses that purchase from smallholders, with the assumption that interventions lead to increased sourcing from smallholders. Other interventions may target improvements in the overall business environment, for example, by facilitating price information to producers and traders or quality information to consumers (The Springfield Centre, 2008). Many interventions target collective producer organizations. Interventions may support the capacity of collective organizations to add value to primary production through more advanced forms of processing, with the expectation that will smallholders will benefit through higher raw material prices. Interventions may also exert leverage over cooperative structures with the aim to increase smallholders' access to important services, such as technical assistance and credit - services for which the private sector, and in some cases, government agencies have been unable to effectively provide. Many interventions also target social objectives of collective organizations (Donovan and Poole, 2013).

Surveys of the literature and numerous case studies confirm the scale of the challenge for developing collective smallholder organizations (Kachule et al., 2005; Donovan et al., 2008; Poole and de Frece, 2010). There is general recognition that such organizations need considerable external support and productive relations with other chain actors; however, analyses and discussions have yet to cover in depth the complex value chain linkages between smallholder suppliers, collective enterprises, external donors and NGOs, and private sector buyers/intermediaries. Bijman et al. (2011) have drawn attention to the importance of community and democratic governance of cooperatives in value chains. They highlight the tension that arises as a cooperative grows or becomes more heterogeneous, whereby the benefits of democratic governance become attenuated by hierarchical arrangements as the need for efficiency increases. Thus the relationship between cooperative organization structure, strategy and performance are critical. Nevertheless, Bijman et al. (2011) do not consider how tensions between these variables affect stakeholders external to the cooperative, which are no less important for efficient management than the tensions common among internal stakeholders (Ortiz-Miranda et al., 2010). While touching on important issues, their paper is more conceptual than empirical. 
Among other reports, recent action research has explored "upgrading" as a means for poor producers to escape poverty (Mitchell and Coles, 2011), and also how fair trade organic cooperatives, such as those for coffee export, can create multiple benefits for members and poor households (Gitter et al., 2012). Nevertheless, more detailed cases are needed of enterprise linkages throughout the chain. In particular, the role of cooperatives in value chains needs more examination as they attempt to address the socioeconomic needs of small-scale producers and the market efficiency and sustainability concerns of other stakeholders: donors, NGOs, and private sector buyers.

This paper examines the potential of cooperatives to engage with development organizations and commercial buyers to improve their business and social performance. It recognizes that cooperatives have the double burden of developing into viable businesses in altogether difficult environments by helping members to upgrade their productive economic capacities and business linkages between growersuppliers and international markets, as well as addressing broader development objectives such as empowerment. We report a case study of a large Nicaraguan coffee cooperative, Soppexcca, which received substantial donor and buyer support at the time of the international coffee crisis between 1999 and 2004 - a period when coffee prices fell below the cost of production for many smallholders in Central America (Bacon, 2005). External support was used in part to build the management capacities of Soppexcca and its assets for processing, storage, and transport of coffee. However, most of the support addressed the direct needs of the Soppexcca membership, including the need to revitalize coffee production following the crisis. The paper draws on livelihoods literature and develops a framework linking investments in capital asset formation and cooperative performance, and throws light on the significance and development of links between producers, collective organization, the private sector and market development donor organizations.

Section 2 reflects on collective organizations[1] and business viability, and introduces the asset framework for the assessment of Soppexcca. Section 3 provides background information on Nicaragua, introduces the case study cooperative Soppexcca, and describes the interventions for developing the value chain. Section 4 explains the methods used for data collection. Section 5 presents the results concerning the changes in asset endowments over the five-year period 2005-2009. In the final section, we discuss the implications of the finding for the design and assessment of organization development: the Soppexcca case illustrates in particular the pitfalls faced, the support received, and potential short-cuts for achieving cooperative development in less time and with fewer resources.

\section{Rural collective organizations}

Forming sustainable value chain links between smallholder farmers and buyers of specialty food products typically requires long-term support in building the capacities of producer organizations. There is much evidence that collective enterprise can play an important role in building sustainable market linkages between smallholders and intermediary firms by correcting some market imperfections such as high transaction costs and missing credit markets, and filling coordination gaps (Sergaki, 2010; Gitter et al., 2012). Moreover, by organizing collectively, smallholder farmers may be more able to obtain necessary information, reach quality standards, and operate on a larger scale by pooling their financial and labor resources (Markelova et al., 2009). There is also evidence that farmer-run cooperatives can assume important roles in agricultural 
JADEE 4,2

136 development based around technology generation and product transformation (Bebbington et al., 1996; Molnar et al., 2007; Abebaw and Haile, 2013).

The commitment of international agencies to cooperatives is unchanging. A recent Parliamentary report to the UK government recommends policies which direct development support to collective enterprise through organizations such as cooperatives (House of Commons International Development Committee, 2013), and follows reiterated commitments by major international organizations. Nevertheless, there are emerging differences in modalities of delivering support. For example, like many other organizations, the World Bank continues to advocate the strengthening of producer organizations as a means for increasing smallholders' access per se to market opportunities and to enhance empowerment (World Bank, 2007, 2013). However, a business focus through improved supply chain management and coordination with the private sector is also considered essential to compete in growing higher-value markets. The World Bank strategy of linking with the private sector is endorsed by the FAO in its latest report on The State of Food and Agriculture (FAO, 2013). IFAD, on the other hand, also committed to smallholder farming, are pioneering an approach whereby funding of producer organizations is being channeled by a government directly to the farmers (IFAD, 2013). The existence of a strong national confederation of farmer organizations is a significant enabling feature of this intervention.

No one best way has been found to support the development of producer organizations. There have been many poor experiences, and also successes tempered by disadvantages. Poole and de Frece (2010) and Mitchell and Coles (2011) among others have analyzed and summarized the strengths and weaknesses of formal cooperatives. Cooperatives tend to have diverse concurrent and often conflicting objectives which can be summarized in two points: first, economic and business development; and second, social inclusion and empowerment. The part that organizational capacity building plays in creating viable enterprises is foundational. A persistent theme is that farmer cooperatives lack financial capital to grow in scale and complexity, particularly for investment in physical assets and value addition through processing and manufacturing. They also lack human capital in the form of professional management and efficient governance. Market operations and relationships with both supplier members and buyers tend to be bureaucratic and unresponsive. Moreover, rural cooperatives tend to operate in environments that do not favor enterprise development and suffer from incomplete and irregular access to technical, business, and financial services. According to Poole and de Frece (2010) there are many features of groups and management that are known to be important for producer cooperatives, and there is no absolute guidance about what does and does not work. As circumstances vary, different features can enhance or impair group performance. For a second tier cooperative such as the Nicaraguan cooperative Soppexcca, which is the object of this study, first, the relationship with the membership of the base cooperatives is an important dimension. Second, critical to its international exports will be the enterprise linkages with the downstream buyers who supply coffee to overseas markets. Finally, relationships with development organizations and lenders are important for providing services to poor small-scale coffee producers, such as technical assistance and credit; for addressing environmental concerns and improving the wellbeing of its members; and for financing long-term investments in infrastructure expansion.

Despite the various theoretical explanations for the failure or underperformance, investment in cooperatives remains an important tool for addressing the social and economic objectives of rural development. The fundamental reasons for collaborating 
continue to hold true: the potential for exploiting production and managerial economies of scale, overcoming market entry barriers, reducing transaction costs, and cultivating supply chain relationships. Where collective organization is necessary for linking producers with private sector development, the key question becomes, how to develop viable cooperatives with fewer external resources and in less time? As noted above, the ability of cooperatives to build their organizational assets, in the form of human, social, financial, and physical assets is critical. But asset building alone is not sufficient to achieve economic and social objectives. In addition, the mechanisms for leveraging assets depend on the organizational characteristics of structure, strategy, and empowerment (Kachule et al., 2005). Poole and de Frece (2010) develop these notions as follows:

(1) Structure: performance is closely linked to organizational structure with respect to scale and scope of activities (such as delivering input supplies, provision of information and training, product processing and accessing markets), constitution and governance, and management attributes.

(2) Strategy: the deliberative processes whereby organizations develop market position and power in negotiation through alliances and scale, and the creation and/or exploitation of sustainable competitive advantages - but these depend on the dynamics of values, governance, and leadership.

(3) Empowerment: mainly concerned with the creation of social and other forms of capital assets, empowerment comes about through participation, individual and collective capacity building, representation, and democratic governance.

(4) Performance: the outcomes are measured against economic and social objectives indicating the extent to which the organization achieves higher levels of efficiency (financial stability and investment in assets) and effectiveness (quality of goods and services provided) - and equity (distribution of risks and rewards, rights and responsibilities). In an agro-ecological context, environmental sustainability considerations assume major importance.

The following framework summarizes how pre-existing organizational capital assets, plus external development inputs in the form of technical, financial, and other support from donors and value chain partners, condition the structure and strategy of the organization. Additionally, in the case of a collective entity, the member empowerment processes are fundamental for organization-building. These elements condition the performance of the organizations (and in turn are influenced by performance), as shown in Figure 1.

In this study, indicators of changes in capital assets were assessed for the coffee cooperative and for the changes in the quality of its upstream and downstream chain links, in order to assess the impact of interventions aimed at improving structure, strategy, and empowerment with respect to business viability and linkages between grower-suppliers and international markets.

\section{Case study background}

3.1 Nicaragua, the coffee crisis and poverty reduction

Nicaragua is the second poorest country in Latin America after Haiti and has a significant rural sector. Agricultural exports total almost 75 percent of total exports (Commodities Street Journal, 2012). World Bank data show that agricultural value 


\section{JADEE 4,2}

\section{8}

Figure 1.

Leveraging assets and external resources for organizational performance

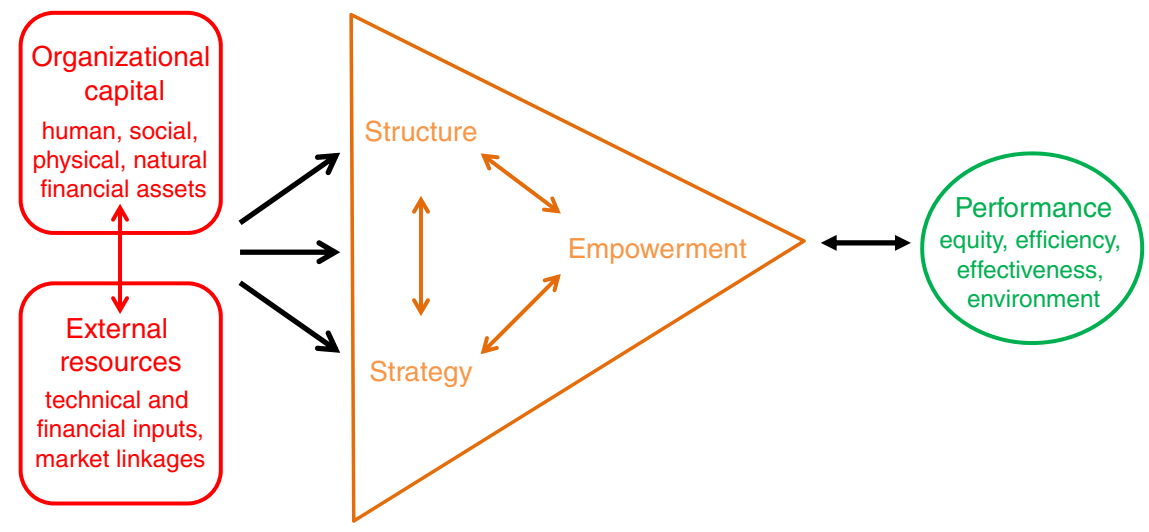

added as a proportion of GDP reached 21.5 percent in 2011 after fluctuating between 18.3 and 20.2 percent during the period 2001-2010 (World Bank, 2012). Among agricultural products exported by Nicaragua, coffee is the most important, comprising 37 percent of the total value of agricultural exports in 2008 (CEPAL, 2009). The recent history of coffee production in Nicaragua is marked by the "coffee crisis" - a period between 1999 and 2004 when prices did not allow coffee producers to cover their variable costs of production, causing major economic and social hardship to producers and laborers, as well as reduced investment in coffee production.

At the time of the coffee crisis, there were about 48,000 coffee farmers in Nicaragua, 80 percent of whom were small producers with $<3.5$ ha under cultivation (Flores et al., 2002). Nicaragua's average coffee productivity, at 1,480 pounds/ha, made it one of the least productive producers of Central America, at roughly 50 percent the productivity of Costa Rica and 40 percent the productivity of Guatemala (Varangis et al., 2003). Despite the large number of smallholders, farms larger than 3.5 ha produced more than 85 percent of the national coffee harvest due to higher intensity of management and access to purchased production inputs.

Among donors, academics, and NGOs, consensus emerged that the most promising response in Central America to the coffee crisis involved developing market linkages between smallholder producers and buyers of specialty coffee, including certified fairtrade and organic coffee (USAID, 2004; Kilian et al., 2006). Development interventions focussed on improving quality in production and post-harvest management, facilitating access to organic and fair-trade certification, and strengthening collective organizations.

Two significant findings from the coffee crisis are relevant: first, certification enhanced prices and market prospects. According to Bacon (2005), during the coffee crisis, price premia rose to approximately 40-50 percent over prices offered by local intermediaries, and cooperatives secured access to credit and more favorable marketing conditions. Valkila and Nygren (2010) agree that successful Nicaraguan fairtrade certified cooperatives were able to pay a significantly higher price to members than the mainstream market; they cite Soppexcca, the object of this study, as having paid members 84 US cents/pound (lb) of green coffee during the 2003-2004 season compared with Exportadora Atlantic SA, one of the largest corporate coffee exporters, which paid on average 48.8 US cents/lb in the period December 1, 2003-March 31, 2004. Recent assessments of production in Nicaragua have highlighted the need to support 
smallholders' ability to enhance coffee productivity, in addition to quality enhancement and achieving certification (Valkila, 2009; Wilson, 2010). Subsequent work has continued to highlight the importance of quality and certification in specialty coffee markets. González-Pérez and Gutiérrez-Viana (2012) reported a comparative analysis of the coffee trade in Vietnam and Colombia, respectively, the second and third largest producing countries after Brazil. They identified the attention given in Colombia to quality, social, and environmental considerations as a source of competitive advantage in specialty consumer markets, compared with Vietnam where cost advantages prevail.

Second, improvements in production and marketing, including certification, have been made possible through collective organization. The study by Haggar et al. (2012) of the costs and benefits of coffee production in Nicaragua illustrates the growing importance of sustainable certification to the country and more specifically for smallholders. Besides the environmental and economic analysis, they also analyzed the management capacity building program for two farmer cooperatives that commercialize certified coffee. The results of the training were found to differ between the two organizations depending on initial capacities. The authors assert that achieving successful accreditation is a lengthy process consuming considerable management and administrative resources, and significantly, external financial support from private sector coffee traders or from donors is necessary. Cooperatives are not the only model for business development, but, as shown below, are a predominant feature of the Nicaraguan policy and organizational landscape.

\subsection{Nicaragua and the cooperative movement}

Historically, in Nicaragua as in other countries, cooperatives have been not just an alternative form of business organization, but specifically an integral part of a social movement with political undertones. Kroeker (1996) traced the historical background of the cooperative movement in Nicaragua to grassroots efforts in the 1930s to redress inequalities of land tenure and economic opportunity. Prior to 1979, and more explicitly

under the Sandinista regime during the 1980s onwards, the ideal was empowerment of the poor and powerless through collective action, new structures and relationships: for Nicaragua, "Empowerment' refers to the ability of individuals and groups to act on their own to achieve their self-defined goals" (Bacon, 2010, p. 53). Bacon distinguished three types of empowerment: personal, relational, and collective. In practice, overformalization of cooperatives and contradictions in support policies of the Sandinista government post-1979 limited empowerment and the development of autonomous and sustainable collective organizations.

Coherence within the cooperative movement was frustrated by the years of civil war and ineffective post-war governance. After the Sandinista government lost elections in 1990, the role of the state in the coffee sector declined. Conflict, agrarian reform, and cooperative development under the Sandinista government post-1979 created a path dependence in agrarian development and enterprise in favor of cooperative organization; in the words of Fraser et al. (2013, p. 10): "memories of the war and expectations that policy reform could provide access to land and services have each played their part in the process of imagining development in a country on the edge of the world economy."

Kroeker (1996) outlined how a widespread lack of leadership and sustainable and professional management skills hampered organizational development within national institutions which led to declining sectoral support and the collapse of weaker 
JADEE

4,2

140 cooperatives. Her overall argument was that cooperative organizations needed a longterm process of "accompaniment" by outsiders who were willing to gain a profound understanding of the grassroots reality at the same time as introducing expertise to promote organizational growth and empowerment. Bacon (2010) also emphasized the historical dimension of Nicaraguan cooperative organization. Like Kroeker, he reported how the cooperative movement served as a means whereby smallholders might preserve their social and economic empowerment and enhance their opportunities through integration into fair-trade networks. The latter surge in cooperative development was an explicit response to the global coffee crisis. Collaborative innovations in market linkages were developed to attenuate the plunge in product prices, including the development of "relationship coffees." Thus cooperatives were the prevailing focus of smallholder organization, the target of interventions by international donors and NGOs, and the means of gaining certification, specialty market positioning and price premia in discerning consumer markets.

\subsection{The origins of Soppexcca}

The case study presented here focusses on one such organizational intervention, Soppexcca. Critical support came from a group of European coffee buyers who were seeking to recuperate their financial losses following the collapse of Soppexcca's predecessor cooperative, Jiprocoop. In 1997, after five years of exporting fair-trade coffee to European buyers, Jiprocoop had declared that it would not be able to meet its contractual obligations for the delivery of green coffee. During the previous year, Jiprocoop had received US\$640,000 in "pre-financing" from six buyers (approximately 60 percent of the value of the contracts). However, poor oversight of the cooperative's administration allowed for theft of the pre-financing by the cooperative's manager and the Export Committee (Denaux, 2008). Without funds for pre-financing, Jiprocoop was unable to establish supply agreements with its members and thus was unable to obtain the coffee needed to repay the pre-financing. By 1999, Jiprocoop's debt, including interest, to its buyers had reached US\$722,991. Jiprocoop was declared insolvent in 1997.

Following the insolvency of Jiprocoop, five of the six European debt-holding coffee buyers offered a solution for repaying the debt, based on their lack of confidence in cooperative governance structures for making the sacrifices required to repay the debt. A new corporate entity would be created which would hold the debt of the defunct Jiprocoop, with which the buyers would continue to trade. This offered the prospects of recovering the losses incurred by mismanagement, ensuring supplies to the European market of the high-quality coffee, and at the same time pursuing the development agenda for the coffee growers. Thus was created Soppexcca, a firm in which the buyers would have a strong management hand, constituted as a "corporation," rather than a cooperative. The corporate structure enabled efficient and professional governance in the interests of shareholders first rather than other stakeholders such as the coffee growers - and avoided the collective and democratic governance and returns to membership associated with common cooperative principles.

The five debt-holding coffee buyers held the majority of shares in the newly formed corporation. They froze interest on the debt, continued to buy coffee from Soppexcca with pre-financing. Producer-members agreed to repay the debt through 50 percent reductions in their price premiums for certified coffee. Soppexcca gradually repaid its debt obligations and expanded commercial relations with coffee buyers in the USA. Asset-building interventions by external organizations helped to return the organization to viability. 
In 2004 the buyer/owners allowed Soppexcca to be reorganized itself as a cooperative with producer-members' interests paramount, but retaining the professional management. The reversion to the cooperative form post-recovery reflected a desire to return the organization to the hands of the member-stakeholders, to avoid taxes not levied on cooperatives and to receive further support from development organizations that would be unavailable to a corporate organization.

At the time of the research, Soppexcca incorporated 16 base cooperatives, each electing two representatives to participate in the general assembly, from which Soppexcca's volunteer member-leaders were elected (e.g. president, vice president, members of the oversight, and credit committees).

\subsection{Interventions and asset rebuilding}

Between 2003 and 2009, Soppexcca received technical and financial support from NGOs and bilateral donors and credit services from fair-trade lending organizations that totaled approximately US\$2.1 million. These interventions and services provided for the following investments in Soppexcca itself and in its service offer to members:

(1) infrastructure development, including the purchase of a dry-mill, offices for Soppexcca and 11 of its base cooperatives, equipment for two retail coffee shops;

(2) provision of technical assistance to members, for both conventional and organic production;

(3) provision of short and long-term credit to members for coffee production, the rejuvenation of coffee plantations following the crisis, and for upgrading wet-milling infrastructure;

(4) quality and productivity enhancement, including construction of a cupping laboratory, soil and water analysis, training program for extension agents, and construction of an organic fertilizer production plant; and

(5) addressing symptoms of poverty beyond coffee, including provision of health and educational supplies to Soppexcca members, as well as support for education and training in cooperative leadership.

The considerable financial and technical support provided to Soppexcca can be rationalized in the context of the coffee crisis, the inability of the Nicaraguan government to provide services to the coffee sector, and the overall importance of coffee for achieving social and environmental goals, and the self-interest of commercial partners. Between 2002 and 2006, Soppexcca's membership increased from 150 to 500. This was due, in part, to the coffee crisis (with households seeking better marketing opportunities), and by Soppexcca's efforts to support households with newly acquired rights over their land.

\section{Study design and methods}

This case forms part of a larger effort by the Ford Foundation and international researchers and practitioners to better understand the ability of smallholders to participate in and benefit from value chain development (Donovan and Stoian, 2012). An important focus of attention was the role of collective action in facilitating the participation of smallholders in value chains for more demanding markets, how interventions can help build such collective organizational assets, and thus how such 
JADEE

4,2

142 organizations can pursue the desired performance objectives. The focus here is on organization-building. NGOs, projects, and non-for-profit lending organizations provided technical and financial support aimed to address the negative implications of the coffee crisis through the building of relationships in certified coffee markets. Support from the private sector included services that were embedded in trading relationships, such as no-interest advance payments on coffee purchases.

After exploratory and participatory research to validate concepts and methodology, asset changes were assessed using a series of indicators for human, social, physical, and financial capital. For Soppexcca, the following proxy indicators were used to identify the extent to which the organization is able to leverage its characteristics of structure, strategy, empowerment, and performance for achieving economic and social objectives:

(1) Human capital: networking building with external stakeholders, development of technical skills for coffee production.

(2) Social capital: reciprocity in value chain relationships with coffee buyers, investments in governance skills.

(3) Physical capital: investments in machinery and infrastructure for primary production and value addition.

(4) Financial capital: loan repayment and provision of member finance.

Data collection were conducted in Jinotega and Matagalpa (north-central Nicaragua) throughout 2009 and focussed on organization-building and changes in the business viability of Soppexcca during the period 2004/2005-2008/2009. More than 20 key informant interviews were carried out with Soppexcca leaders, international coffee buyers, certification agents, and other relevant actors and were supplemented by secondary information from Soppexcca. These data were triangulated against survey data from 296 of the roughly 500 members of the cooperative, covering 11 of Soppexcca's 18 base cooperatives. To the extent possible, quantitative information was collected to understand the changes in assets, and qualitative information was used to understand the relevance of and the reasons for the changes.

\section{Results}

This section examines changes in capital assets of the coffee cooperative Soppexcca and the extent to which these changes led to improved business viability in terms of organizational structure, strategy, performance, and empowerment. As detailed in the following discussions, Soppexcca achieved major advances in asset building and these interventions played a pivotal role in building the organization's capacity to respond to buyers' demands and market-related shocks. However, results also show that important gaps remain and that addressing these gaps implies changes in how Soppexcca operates and in how interventions for value chain development are designed and assessed.

\subsection{Human capital}

This section evaluates changes in skills and capacities of Soppexcca's governance to sustain relations with buyers, NGOs, and member households; provide effective technical assistance to members; and develop the governance skills and capacities of elected leaders. 
5.1.1 Networking with buyers and NGOs. Before the assessment period, Soppexcca had demonstrated an ability to contract buyers for the purchase and selling of coffee and secure NGO collaboration for supporting smallholder producers. This was due, in large part, to the installation by the debt-holding coffee buyers of a professional manager whose salary during her first years of service was covered from external sources. Since the beginning of Soppexcca, she had been responsible for all strategic planning. All the coffee buyers interviewed for this study expressed their unconditional trust in the cooperative's management. However, they also mentioned how communication stopped when the manager was out of contact and that the overall costs of coordination with Soppexcca were high, due to information blackouts.

Similarly, NGOs commented that they found difficulty in obtaining timely information from Soppexcca to comply with its donor reporting requirements. There too, information blackouts were common, best resolved through repeated and frequent visits by NGO staff to Soppexcca offices. The organization struggled with managing the information demands by buyers and NGOs, in addition to the information needed to run their business and evidence suggests that while Soppexcca management had the skills, it lack the capacity to manage effectively the many demands placed on it by buyers, NGOs, and other service providers and by members.

5.1.2 Investments in technical assistance. Good practices in production, harvesting, and wet-milling are essential for delivery of quality coffee to the processor-exporters. For most households interviewed, Soppexcca was the only provider of technical assistance during the assessment period, and substantial investments were made. Beginning in 2007, a team of eight extensionists was employed to provide technical assistance and access to development projects, which have played a role in expanding the options available for agricultural production (e.g. cocoa, small livestock). Soppexcca's human capacity to provide technical assistance expanded markedly during the assessment period but remained dangerously dependent on external support. Despite the increase in staff from two prior to 2006, to seven in 2007, their overall capacity to provide technical assistance was limited by the scope of activities. Extensionists were charged with assisting households in coffee production and post-harvest management, estimating and monitoring coffee production for the credit department, and participating in and carrying out training on various social subjects such as gender promotion. Each extensionist was assigned to between one and three base cooperatives. The salaries of all extensionists were covered entirely by project funds. At the time of data collection, the renewal of contracts for five extensionists was in jeopardy, subject to new sources of funding.

According to evidence from household and key informant interviews extensionists were not equipped with the incentives, tools, or training to address the farm-level production problems of resource-poor households. Among the concerns expressed, the lead extensionist said that staff were overburdened (each extensionist with 60-70 households) and were unable to target assistance to households based on need. There was a lack of coordination between technical assistance and the credit department, and they suffered from low motivation and limited skills (three were fired in 2009 for low performance or unprofessional behavior), a tendency to provide recommendations with limited understanding of the coffee plantation, and poor skills to communicate effectively with primary producers. Members commonly pointed to a lack of attention and capacity to identify appropriate solutions to technical production problems. Developing and retaining qualified staff was a problem. In general, the insecure 
JADEE

4,2

144 contractual situation was identified by extensionists during interviews as a major source of concern. Physical insecurity was also a factor: in 2009, a newly hired extensionist was murdered in an attempted robbery while returning from a base-cooperative training event.

Weaknesses in technical capacity were evident in the perceptions by members of the quality of services provided between 2007/2008 and 2008/2009. Among the sampled households, 44 percent $(n=129)$ reported being dissatisfied or highly dissatisfied with

technical assistance provision. Selected household responses shed light on the nature of the problem:

Household \#26: "We were visited once in 2008, but the extensionist didn't provide technical advice; he arrived to inform us of a meeting at the cooperative."

Household \#265: "I lack advice when I need it: on one occasion I requested a visit from the extensionist because the coffee berries were falling off the branches, but he never arrived."

Household \#277: "Visits are only for estimating the harvest - the extensionist does not know my coffee plantation. He sends others from the community to assist me and does not provide recommendations."

\subsection{Social capital}

The nature and strength of Soppexcca's relationships with its buyers and its members provides the basis for analysis of social capital endowment. The member survey and key informant interviews with staff, elected leaders, and coffee buyers provided the information for assessment.

5.2.1 Relationships with buyers. The 2008-2009 harvest was sold to seven buyers: five from Europe, who purchased 59 percent of the total volume exported, and two from the USA, who purchased the remaining 41 percent. The five European buyers had purchased roughly the same amount of coffee (usually between one and two containers per year) from Soppexcca every year since 1999 - the year that Soppexcca first exported coffee after Jiprocoop's collapse. US buyers began to purchase coffee after the 2003-2004 harvest. The addition of the US buyers followed a period of rapid expansion in membership which allowed for increased export volumes. Interviews with European buyers suggested that strong links existed before the assessment period, due initially to Soppexcca's commitment to repay the debt left behind by Jiprocoop. Effective professional management and compliance with contractual terms reinforced this initial trust over time. None of the interviewed buyers reported major problems over the quality of coffee delivered or with compliance with contractual terms (including repayment of pre-financing). One buyer regarded Soppexcca as the most reliable among the ten cooperatives in Latin America from which it purchased coffee.

Buyers were asked to identify problems encountered in their communication and coordination with Soppexcca during their business relationship. Responses indicated that relationships exhibited unusually high levels of trust, on the one hand, and frustration at the inefficiency of communications and apprehension regarding Soppexcca's viability, on the other. According to one buyer:

We feel a special trust with Soppexcca. They kept paying off the debt even though they didn't have to.

Trust was reflected in tangible ways. For example, when Soppexcca expressed concerns about its difficulty to capture its members' coffee due to high levels of local 
competition during the harvest season, buyers agreed to adjust their price formula so that prices offered were more in line with local prices. One noted that:

If Soppexcca has to request an adjustment in their price, then there is always a good and transparent reason.

\section{Building cooperative \\ capacity}

145

However, communication and coordination was criticized. Buyers reported information blackouts when Soppexcca experienced problems with delivery of a container. Lack of communication about delays left buyers unprepared for the arrival of containers, resulting in extra port charges incurred by the buyer. Communication tended to suffer when the manager was away:

It is very hard to get communication from other Soppexcca staff; communication is very much focused on [the manager] noted one buyer.

Given the inherently risky nature of coffee production efficient communication is prized by buyers. One buyer made an annual trip to Soppexcca's office to get information on expected production volumes and local marketing conditions. Information collected also provided the buyer with inputs for the promotion of their product in Europe. The buyer added:

We would prefer that the information we need were provided in a less costly manner, but we have learned to adjust to the situation.

While overall confidence in Soppexcca by its buyers was exceptionally high prior to and during the assessment period, buyers expressed concern about the durability of their business relationship, especially due to the concentration of responsibility in the manager. As stated by one buyer:

What would happen if [she] left? It would be hard to understand the change in our relationship with Soppexcca if she left [...] We want and need more people in Soppexcca that we can rely on.

5.2.2 Investment in elected leaders. Evidence during the assessment period indicated that the Board faced major challenges in effective governance. The election of memberleaders first became part of Soppexcca's organizational structure when it converted to a cooperative business. The Board of Directors first met in 2004 and then met regularly to discuss strategic and operational decisions, such as relations with buyers, credit providers, and NGOs and setting prices for Soppexcca-provided credit. However, key informants within and outside Soppexcca argued that the Board failed to carry out its governance duties fully and effectively. One reason for this was a lack of information on the strategic objectives of Soppexcca or its financial status. Two key informants with leadership roles on the Board of Directors in 2009 commented that they were unaware of the strategic plan and that they had not been able to access up-to-date and usable information on the financial status. They attributed the lack of financial information to weaknesses in the administrative department.

Moreover, according to a former member of the Oversight Committee, whose role it was to monitor financial affairs, during the first two years of this three-year term, he did not understand how to interpret financial statements. It was not until the final year of this term that he consulted with an externally hired accountant to review in detail the financial statements.

Another commented that she received no training in basic business or in cooperative management prior to assuming her post. She claimed that during her entire period on 
JADEE

4,2

146 the Board she had little understanding of how the farmgate price was calculated or of the contract price for coffee between Soppexcca and its European and US buyers. What skills and knowledge she gained while on the Board were acquired through trial and error - a potentially effective yet costly approach to building human and social capital.

Interviews highlighted Board members' reluctance to probe the management on strategic decisions and investments. Interviews with former Board members also indicated that the Board did not set the agenda for its meetings; rather management set the agenda, with no consultation. According to one former Board member:

Any effort to discuss the decentralization of Soppexcca's administration drew criticism from the other Board members because it was perceived to show a lack of respect for [the manager].

\subsection{Physical capital}

Notable additions to Soppexcca's physical capital took place during the assessment period. Soppexcca began the period with a warehouse financed by donor grants that received and stored coffee and housed the administrative and technical staff. By the end of the assessment period, the following additions had been made to physical capital:

(1) 11 basic offices for base cooperatives were constructed in 2008 with project funds for housing extensionists and providing space for meetings and the storage of coffee.

(2) A cupping lab was constructed in Matagalpa in 2005 with financial assistance from an NGO and a US coffee buyer to implement internal quality control procedures and develop quality-consciousness among members.

(3) In 2007, to add value to green coffee, two retail cafés were constructed in Jinotega which boosted cooperative revenues and provided employment opportunities for a small staff derived from the membership.

(4) In 2008, a facility was constructed for the production of chicken-manure fertilizer to reduce dependence on purchased organic fertilizer and provide for an additional source of operating funds.

(5) In 2008, Soppexcca purchased its own processing plant at a cost of US\$614,344. Own funds (US\$119,344) were derived from the fair-trade premium, and supplemented by a long-term loan from an US-based lending organization (US\$280,000) and NGO donations (US\$215,000).

(6) Other equipment: between 2003 and 2009 additional equipment was acquired such as trucks, computers and office equipment, mainly with grants from project funds.

Grants from bilateral donors were essential for building physical capital. From the perspective of both donors, such investments were in line with their strategy for increasing the competitiveness of the Central America coffee sector in terms of improved quality and increased value added. These investments allowed the organization to increase the range of services offered to members and its income-generating potential.

\subsection{Financial capital}

5.4.1 Loan repayment. To appreciate how far Soppexcca advanced in financial capital endowments over the assessment period, a brief reminder of its debt is necessary. 
At the start of the assessment period, Soppexcca still had roughly US\$450,000 in outstanding debt from its predecessor organization. Moreover, it had little to offer its members in terms of short-term credit - critical for the purchase of fertilizer and for carrying out coffee tree maintenance. By 2008, however, the debt had been paid off, it expanded its short-term credit portfolio to approximately US\$300,000, and provided long-term credit to its members. This section discusses how these changes were possible and addresses the remaining major challenges for further building its financial capital endowments.

Two factors played a major role in the ability to repay the debt inherited from Jiprocoop:

(1) First, sales of coffee by volume increased significantly during the $2000 \mathrm{~s}$, on average by 25 percent per year between 2001/2002 and 2007/2008. Not only did sales volumes increase and benefit from the certification price premium, but Soppexcca diversified its market outlets, making a significant inroad into the US market.

(2) The other contributing factor was the willingness of affiliated households to accept reduced coffee prices during the period between 2000/2001 and 2007/2008. Producers relinquished 50 percent of the premium obtained from certification during these years. This arrangement required a major sacrifice on the part of producing households, as well as a high level of commitment to the debt-holding coffee buyers.

5.4.2 Capitalization of credit program. Provision of short-term credit secures access to parchment (dried but unhulled, therefore semi-processed) coffee. Given the lack of affordable credit for smallholders, access to the credit program provided powerful incentives for members to comply with the credit terms and to gain benefits to offset the higher costs of doing business with Soppexcca such as delayed final payment, higher quality requirements and lack of transport services. Between 2001/2002 and 2007/2008, Soppexcca achieved a major increase in the size of its short-term credit portfolio. Delinquency in repayment was a major problem, largely due to the diversion of credit for other purposes. The increase in the credit portfolio was due to the direct injection of funds by projects and donors for short-term credit and by the transfer of funding from long-term credit to short-term credit upon repayment of long-term credit by members.

The offer of long-term credit to members is rare among coffee cooperatives in Nicaragua. Long-term credit was especially critical because it allowed members to renew their plantations and expand their coffee holdings. Long-term credit was first offered in 2002/2003. The total size of the long-term credit portfolio varied from year to year. In 2007/2008, US\$83,303 was offered as long-term credit, all derived from project funds. Soppexcca's ability to access funds for long-term credit reflects its strong links with NGOs during the coffee crisis.

Repayments of long-term loans were channeled into the short-term credit program rather than reused to provide long-term credit. This reflected the high risks related to long-term credit provision as well as the more urgent need to secure access to parchment coffee through the provision of short-term credit.

\subsection{Summarizing the principal findings}

On the surface, the cooperative appears to be a significant success. Soppexcca repaid its debt and achieved major advances in asset formation, with external interventions playing a pivotal role in building capacity to respond to buyers' demands and market-related shocks. The linkage to export markets offering guaranteed sales at 
JADEE

4,2

148 premium prices was the fundamental strategic advantage of the enterprise model. Moreover, the linkages to external sources of finance and use of the social premium from fair-trade sales provided much-needed funds for paying down the debt and for making investments in other forms of capital.

But there are important gaps and weaknesses in asset building that limit its ability to deliver sustainable benefits to its membership base and reduce its vulnerability to internal and external shocks:

(1) The strong professional leadership, combined with a long-term commitment from buyers and NGOs, and the institutional framework provided by fair-trade certification, all played an important role in building the organization, and creating trust among external stakeholders.

(2) Relationships between Soppexcca and international buyers were characterized by high levels of trust, successful flows of high-quality products, but accompanying information flows were managed less efficiently. Management responsibility was highly centralized. Therefore, while external stakeholders were confident in the actual performance of the cooperative, at the same time they were concerned about the sustainability of the management model.

(3) There were also significant internal management weaknesses: strong personal relationships and trust were not supplemented by adequate flows of management information; the need among members for technical assistance was large and services provision by Soppexcca was constrained by inadequate management, human and financial resources. Technical assistance depended on external finance which was limited in scope and delivery, and was not integrated with the servicing of other business functions such as credit management.

(4) The intention to democratize governance and empower the membership was afflicted by similar management weaknesses. Lack of training of elected officials, inadequate information flows and lack of strategic vision left governance highly centralized, with a lack of willingness to empower the membership. Thus, the conversion from corporation to cooperative was somewhat incomplete, and exposes the cooperative to serious management risks.

(5) Social capital-building among the base membership was strong: the provision of support for health, education, and safety-net services, for example, in the case of sudden death of family members, was identified by members as a very important mechanism for strengthening social networks.

(6) Notable additions to Soppexcca's physical capital were essential for operating in the high value export markets. Infrastructure development was crucial to ensure Soppexcca's long-term ability to sustain relations with buyers and for expanding future income sources (e.g. purchase of dry mill). However, it can be questioned whether the considerable sums invested could have been used more effectively for promoting coffee productivity and other goals among coffee growing communities.

(7) There was substantial loan repayment. The provision of affordable short- and long-term credit with capital from international buyers was critical for strengthening the supply base, and it strengthened the performance and depth of value chain relationships. However, while financial capital endowments were 
built up during the assessment period, the final balance was still weak and Soppexcca remained highly dependent on donor funds. The fact that technical assistance was 100 percent financed by projects was a major concern. Finally, the use of the fair-trade social premium for debt repayment again highlights a dilemma faced by Soppexcca in trying to develop a viable business, while at the same time trying to address the social needs of its membership.

The factors favoring and limiting the development of Soppexcca are summarized in Table I, where weaknesses were often the "flip-side" of strengths:

\section{Discussion and conclusions}

This paper has applied an asset-building lens to assess the development of Soppexcca, and its ability in collaboration with NGOs, international coffee buyers, and others, to improve its business performance and viability, while addressing the other needs of its membership base. Investments made by coffee buyers and external support from

Factors favoring organizational development Constraints to organizational development

Human Strong professional management supported by strong institutional linkages

Strong technical capacity for coffee production, processing, and certification Demonstrated ability to find practical solutions to coffee production and processing

Social Significant support to membership through provision of social services enhances the sense of belonging

Physical Substantial addition to infrastructure for coffee storage and processing

Substantial expansion of administrative space for base cooperatives and the central second-tier organization

Financial Core business operations (collecting, processing, and export of green coffee) appear to be economically viable Considerable loan repayment giving greater financial stability and reduced indebtedness

Effective provision of essential short-term working credit and longer-term loans
Concentration of power in executive management threatens succession and limits sustainability

Absence of feedback loops on the effectiveness of services and weak links between units within the cooperative administration

Inadequate technical support to membership and training of leaders

Vulnerability to management and governance risks

Inadequate communication and information flows

Lack of transparency

Weak democratization and ineffective member participation

Lack of additional infrastructure and logistics provision such as transportation and secure storage to facilitate members' coffee deliveries

Scale limited by low productivity in coffee production and inability to expand credit offer and membership size Dependence on external funds for technical assistance, coffee purchases, infrastructure expansion, and credit programs likely to continue for the short-medium term

\section{Building cooperative capacity}

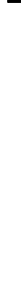

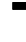

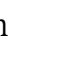


JADEE

4,2

150

NGOs and donors had led to the formation, out of the ashes of its predecessor Jiprocoop, of a new organization called Soppexcca. This pattern conforms to the phenomenon of "phoenix organizations," where a viable organization is re-built out of initial collapse through a new and more rigorous (re-) start-up (Kachule et al., 2005). Initially constituted as a corporation, Soppexcca achieved stability through debt repayment and then entered a period of growth. The turnaround was a function of external support, the imposition of strong management by debt-holding coffee buyers, and a willingness of the membership to accept financial sacrifice in the form of reduced coffee prices. With the mutual agreement of coffee buyers and coffee growers, Soppexcca was reconverted into a collectively owned business. The changes in organizational assets of the renewed cooperative were monitored during the recovery period and need to be set against the framework of organizational structure, strategy, performance and empowerment introduced in Section 2 to assess business sustainability and performance.

Regarding the organizational structure, the growth in membership and in sales improved the economic scale of Soppexcca. The external technical, managerial and financial inputs enhanced the delivery of various services to the membership, and enabled valuable credit services and asset building by the organization - and by members. Future growth in membership, but without additional access to credit lines, signals the need for Soppexcca and its supporters to address the low productivity of its grower-members and ensure coffee supplies of high quality and quantity.

The corporate form initially adopted for the turnaround was successful. Once the international buyers' exposure to the debt risk had been reduced, reversion to a membership organization partially attenuated the external leverage over organizational management. Although the leadership currently in place has been successful, the lack of democratization and transparency suggest that adequate safeguards against the recurrence of the original problems of mismanagement and corruption have not been put in place. Current governance is effective, but comes at the cost of an increased risk to succession following the current manager. The lack of skilled management in Nicaragua means that there has been no alternative.

Regarding strategy, the investments in productive assets by Soppexcca and its members, the development of effective systems for ensuring coffee quality, and the existence of a stable and professional management have positioned Soppexcca firmly in the international certified coffee value chain. These linkages provided the foundation for future interactions with donors and fair-trade organizations, which would later offer the critical support needed for building productive assets and improving quality. The transition to a new membership organization was promoted by the international buyer-partners and enabled producers to maintain access to the competitive specialty fair-trade market and premium prices and to regain the taxation advantages and ease of certification of the cooperative form. Soppexcca's ability to respond to the needs of its buyers has not diminished with collective ownership.

However, evidence of progress towards empowerment of the producer-members was mixed. On one hand, smallholder members' own capacities to engage in higher value and volume coffee production through their link to the resurgent organization was increased. Members often benefited financially through their coffee sales to Soppexcca, although the most significant benefits were concentrated among the larger specialized farmers. Members also achieved first-time access to vital services for 
smallholder coffee production, including technical assistance and credit. The provision of social services by Soppexcca was significant, but was a welfare function rather than something that resulted in member empowerment. On the other hand, the new governance structure did not facilitate effective member participation. There is a significant risk in the failure to engage and train the membership in organizational governance, alongside the potential adverse consequences of the concentration of management power.

Thus, in performance terms, social and economic objectives have both been partially met. However, the tantalizing prospect of long-term sustainability requires a process of serious change in representation, decision making, information handling and human capacity building to sustain the gains in efficiency and effectiveness. It is noteworthy that in her analysis of the ethics of fair trade, Utting (2009) identified a similar management dilemma within a cooperative structure, which is the credibility and operational gap between professional management and membership. She cited the view of Soppexcca's professional manager on this dilemma, being the constraints imposed by high levels of illiteracy of the majority of the cooperative members, low education levels of the representatives on the board and their lack of knowledge about how to manage legal, commercial, organizational and fair trade requirements. This mirrors more widespread cooperative experience and signals that the empowerment dimension is the critical element, or rather the disempowerment of the membership, which must be addressed to ensure the transition to a sustainable organization.

However, both Soppexcca and its members may be reluctant to spread power in a way that could create a management elite, given previous experiences with cooperative mismanagement and the overall shortage of effective business skills in Nicaragua. In theory, a corporate structure could provide greater input into governance and thus represent an improvement over the cooperative structure in Soppexcca's case. After all, it was Soppexcca's previous owners (the debt-holding coffee buyers) who played a key role in establishing the professional management which is credited with Soppexcca's success in its repositioning within certified coffee markets. In practice, neither Soppexcca nor its members are likely to accept a return to the external oversight, especially if this were to result in reduced support from NGOs and projects, the payment of corporate taxes and other fees, and greater uncertainty in certified high-quality product markets.

Important conclusions can be drawn from this case. The first is the advantage of the hybrid member cooperative- secondary corporate structure, and that by being thus organized during a critical stage in its development, Soppexcca likely accelerated its recovery and development as a viable commercial enterprise. It highlights the importance of having strong professional administration, and market linkages during the initial development phase that can subsequently evolve into enduring, profitable private sector linkages. However, the transition from private enterprise to cooperative has not been easy. Soppexcca has struggled to empower its members to contribute to cooperative governance, and NGO and donor partners have not yet emphasized such democratization and empowerment.

Second, on the "quantity" of support, has it been worth it? The considerable external support involved in the restructuring of Soppexcca implies that it may serve as a model for collective enterprise rescue but should not serve as a model for organizational development in most contexts. But Soppexcca is not alone in having received significant intervention: there are other notable examples of high levels of support given to cooperatives that link smallholders to higher-value markets in Latin America 
JADEE

4,2

152 (e.g. Cecocafen in Nicaragua (certified coffee), El Ceibo in Bolivia (organic cacao), Forestcom and El Pino in Guatemala (certified timber and fresh vegetables, respectively), and in Africa (NASFAM in Malawi in diverse agricultural product markets). The Soppexcca case illustrates the willingness of donors and NGOs to support more advanced cooperatives when such support has the potential to impact the wellbeing of smallholder producers. After all, much of the support channeled through Soppexcca was directed towards helping poor coffee growers to build their assets following the coffee crisis. In the context of the coffee crisis, when the external environment was particularly unfavorable for coffee producers, it was not difficult to justify the private and NGO support to rescue the business. And for buyers, the debt was repaid and valued supplies of high quality certified product were secured. But this level of support cannot be widely scaled out.

Third, the case furnishes more evidence also on the quality of support for the creation of sustainable cooperatives. In particular, stimulation of viable collective enterprise is a long-term process and requires patient external support. In this, the experience of Soppexcca again is not unique: also in Nicaragua, Fraser et al. (2013) record the demise due to corruption and mismanagement of the second tier cooperative Giprocoor in the late-1990s. Giprocoor was then reconstituted with an imposed management and the support of European buyers as a private limited company, Sepasa, "to clean up Giprocoor's corruption and uphold fair-trade values through good management and business principles" (p. 12). Smallholders, who had realized the significance of property rights due to previous experience of land appropriation and forced migration, expressed a willingness to repay to European buyers the accumulated debts. Having tied in external commercial support, Sepasa moved into recovery after 2003. Efforts began later to encourage the organization to revert to a cooperative structure.

Soppexcca and Sepasa have more in common. The reasons for formation were partly cultural and ideological: they included the desire that members might have some democratic participation in governance; the awareness that international donor organizations specifically wanted to work with cooperatives. Equally important were the business reasons, to minimize the organization's tax burden which is higher for corporate entities than for cooperatives; and to sustain the strong link between the fair trade movement and collective smallholder organization. Moreover, for producers, the memory of the fair trade premium received through sales through the cooperative sector during the coffee crisis will also have persisted. Finally, a favorable macropolitical condition was the return of the Sandinista government in 2007 which created a more enabling environment and lent support to the social empowerment aims of cooperatives: it was said that "the only way to secure social development programs was through further embedding the Union of Organized Cooperatives (UCA) within local cooperative 'reality' [...]' Fraser et al. (2013).

The Soppexcca experience also echoes the analysis by Bebbington et al. (1996) of the development trajectory of the cocoa cooperative El Ceibo in Bolivia. They attributed its success to slow growth through genuine vicissitudes into a complex, multifunctional and modern organization, yet retaining a focus on the core business of cocoa marketing into the international fair trade, organic cocoa sector. They acknowledged that the achievements of El Ceibo "have not come cheaply, and remind us that building capacity in a campesino [sic] organization requires significant and sustained investment of resources" (p. 202). Similarly, among the key factors were the quality of external support: loyal and sensitive donors; the volume and duration of external support: 
sixteen years of continued technical assistance; donor-facilitated direct network linkages into export markets; and a range of organizational support services, including both technical assistance and continued and intense support for the formation of human resources.

In conclusion, Soppexcca is representative of the traumas of forming collective organizations in developing countries, particularly in agribusiness. The intention of this study is not to claim representativeness, however, but there are wider lessons to be learned as the development community reiterates its policies of support to producer organizations. It highlights the long and winding road for development: the level of support suggests that it is a costly success, but many of those business costs have been recovered. For Soppexcca, and for other development initiatives that could benefit from this lesson, the particularly significant dynamic is the valuable and consistent support from networking with business partners, not just working with NGOs and donors (Sergaki, 2010). Donovan et al. (2008) argued that external stakeholders such as donors, NGOs and value chain partners may have to be committed for longer than a medium term of, say, four to five years, with a focus on building the "soft" assets associated with human skills of management and governance. "Soft asset" formation may continue to be necessary for years after the technical assistance, infrastructure and financial support have been scaled down. Thus the need is urgent to create economically sustainable cooperatives in shorter periods of time. Potential short cuts will depend on delivery of effective and well-articulated technical, business and financial services throughout the organizational development process. The design and delivery of these services require alignment and harmonization between government policy, the approaches of development agencies, NGOs, research and training centers to skills training, and most of all, closer collaboration, communication and coordination in the value chain among cooperatives, buyers and processors.

\section{Note}

1. The literature does not often differentiate clearly between diverse organizational forms, using interchangeably such terms such as farmer and producer cooperatives, associations, organizations, and community and collective enterprises. Here we refer to cooperatives as the predominant form of collective organization, one function of which is collective enterprise, which we differentiate from the social functions of cooperatives.

\section{References}

Abebaw, D. and Haile, M.G. (2013), "The impact of cooperatives on agricultural technology adoption: empirical evidence from Ethiopia”, Food Policy, Vol. 38, February, pp. 82-91.

Bacon, C. (2005), "Confronting the coffee crisis: can fair trade, organic, and specialty coffees reduce small-scale farmer vulnerability in Northern Nicaragua?", World Development, Vol. 33 No. 3, pp. 497-511.

Bacon, C.M. (2010), “A spot of coffee in crisis: Nicaraguan smallholder cooperatives, fair trade networks, and gendered empowerment", Latin American Perspectives, Vol. 37 No. 2, pp. 50-71.

Bebbington, A., Quisbert, J. and Trujillo, G. (1996), “Technology and rural development strategies in a small farmer organization: lessons from Bolivia for rural policy and practice", Public Administration and Development, Vol. 16 No. 3, pp. 195-213.

Bijman, J., Muradian, R. and Cechin, A. (2011), "Agricultural cooperatives and value chain coordination", in Helmsing, A.H.J. and Vellema, S. (Eds), Value Chains, Social Inclusion and Economic Development, Chapter 5, Routledge, London, pp. 82-101. 
JADEE 4,2
CEPAL (2009), Nicaragua: Evolución Económica durante 2008 y Perspectivas para 2009. Mexico City, Comisión Económica para América Latina y el Caribe, available at: www.eclac.cl/ publicaciones/xml/1/36681/L913.pdf (accessed May 1, 2012)

Commodities Street Journal (2012), Nicaragua, available at: http://commoditiesstreetjournal.com/ commodity-country-profiles/nicaragua/ (accessed August 22, 2012)

Denaux, G. (2008), Lo Veo y No lo Creo: La Historia de 11 Años de la UCA Soppexcca, Jinotega, Nicaragua.

Donovan, J. and Poole, N.D. (2013), "Asset building in response to value chain development: lessons from taro producers in Nicaragua", International Journal of Agricultural Sustainability, Vol. 11 No. 1, pp. 23-37.

Donovan, J. and Stoian, D. (2012), 5Capitals: A Tool for Assessing the Poverty Impacts of Value Chain Development, CATIE, Turrialba.

Donovan, J., Stoian, D. and Poole, N.D. (2008), "A global review of rural community enterprises: the long and winding road for creating viable businesses, and potential shortcuts", Technical Bulletin No. 29, Rural Enterprise Collection No. 2, CATIE, Turrialba.

FAO (2013), The State of Food and Agriculture 2012, Food and Agriculture Organization of the United Nations, Rome, available at: www.fao.org/docrep/017/i3028e/i3028e.pdf (accessed May 2, 2013)

Flores, M., Bratescu, A., Martínez, J.O., Oviedo, J.A. and Acosta, A. (2002), Centroamérica: El Impacto De La Caída De Los Precios Del Café, Comisión Económica para América Latina y el Caribe, Mexico City, available at: www.eclac.org/cgi-bin/getProd.asp?xml=/ publicaciones/xml/9/9679/P9679.xml\&xsl=/mexico/tpl/p9f.xsl\&base=/tpl/top-bottom.xslt (accessed May 1, 2012).

Fraser, J., Fisher, E. and Arce, A. (2013), "Reframing 'crisis' in fair trade coffee production: trajectories of agrarian change in Nicaragua", Journal of Agrarian Change, Vol. 14 No. 1, pp. 52-73.

Gitter, S.R., Weber, J.G., Barham, B.L., Callenes, M. and Valentine, J.L. (2012), "Fair trade-organic coffee cooperatives, migration, and secondary schooling in Southern Mexico", The Journal of Development Studies, Vol. 48 No. 3, pp. 445-463.

González-Pérez, M.-A. and Gutiérrez-Viana, S. (2012), "Cooperation in coffee markets: the case of Vietnam and Colombia", Journal of Agribusiness in Developing and Emerging Economies, Vol. 2 No. 1, pp. 57-73.

Haggar, J., Jérez, R., Cuadra, L., Alvarado, U. and Soto, G. (2012), "Environmental and economic costs and benefits from sustainable certification of coffee in Nicaragua", Food Chain, Vol. 2 No. 1, pp. 24-41.

House of Commons International Development Committee (2013), "Global food security", first report of session 2013-14, The Stationery Office Limited, London.

Humphrey, J. and Navas-Alemán, L. (2010), Value Chains, Donor Interventions and Poverty Reduction: A Review of Donor Practice, Sussex, Institute of Development Studies, Brighton.

IFAD (2013), Pioneering Direct Farmer Support in Guinea, International Fund for Agricultural Development, Rome, available at: www.ruralpovertyportal.org/country/voice/tags/guinea/ guinea_pioneering (accessed May 2, 2013).

Kachule, R., Poole, N.D. and Dorward, A. (2005), "Farmer organisations in Malawi: the organisation study", Final report for "Farmer Organisations for Market Access", DFID Crop Post Harvest Research Programme (R2875), Imperial College London, London.

Kilian, B., Jones, C., Pratt, L. and Villalobos, A. (2006), "Is sustainable agriculture a viable strategy to improve farm income in Central America? A case study on coffee", Journal of Business Research, Vol. 59 No. 3, pp. 322-330. 
Kroeker, C.J. (1996), "The cooperative movement in Nicaragua: empowerment and accompaniment of severely disadvantaged peasants", Journal of Social Issues, Vol. 52 No. 1, pp. 123-138.

Markelova, H., Meinzen-Dick, R., Hellin, J. and Dohrn, S. (2009), “Collective action for smallholder market access", Food Policy, Vol. 34 No. 1, pp. 1-7.

Mitchell, J. and Coles, C. (Eds) (2011), Markets and Rural Poverty: Upgrading in Value Chains, Earthscan and International Development Research Centre, London and Ottawa.

Molnar, A., Liddle, M., Bracer, C., Khare, A., White, A. and Bull, J. (2007), Community-based Forest Enterprises: Their Status and Potential in Tropical Countries, International Tropical Timber Organization, Yokohama.

Ortiz-Miranda, D., Moreno-Pérez, O.M. and Moragues-Faus, A.M. (2010), "Innovative strategies of agricultural cooperatives in the framework of the new rural development paradigms: the case of the region of Valencia (Spain)", Environment and Planning A, Vol. 42 No. 3, pp. 661-677.

Poole, N.D. and de Frece, A. (2010), A Review of Existing Organisational Forms of Smallholder Farmers' Associations and their Contractual Relationships with other Market Participants in the East and Southern African ACP Region, Food and Agriculture Organization of the United Nations, Rome, available at: www.fao.org/fileadmin/templates/est/AAACP/ eastafrica/FAO_AAACP_Paper_Series_No_11_1_pdf (accessed March 19, 2013).

Poole, N.D., Chitundu, M. and Msoni, R. (2013), "Commercialisation: a meta-approach for agricultural development among smallholder farmers in Africa?", Food Policy, Vol. 41, August, pp. 155-165.

Sergaki, P. (2010), "The role of networks on the competitiveness of agricultural cooperatives and small-medium enterprises along the supply chain in Greece", Food Economics - Acta Agriculturae Scandinavica, Section C, Vol. 7 Nos 2-4, pp. 180-191.

Stoian, D., Donovan, J., Fisk, J. and Muldoon, M. (2012), "Value chain development for rural poverty reduction: a reality check and a warning", Enterprise Development and Microfinance, Vol. 23 No. 1, pp. 54-69.

The Springfield Centre (2008), The Operational Guide for The Making Markets Work for the Poor (M4P) Approach, Department for International Development/Swiss Agency for Development and Cooperation, London and Berne.

USAID (2004), USAID Supports Coffee Growers Around the Globe, USAID, Washington, DC, available at: http://pdf.usaid.gov/pdf_docs/PDACA587.pdf (accessed May 1, 2012).

Utting, K. (2009), "Assessing the impact of fair trade coffee: towards an integrative framework", Journal of Business Ethics, Vol. 86 No. S1, pp. 127-149.

Valkila, J. (2009), "Fair trade organic coffee in Nicaragua: sustainable development or poverty trap?", Ecological Economics, Vol. 68 No. 12, pp. 3018-3025.

Valkila, J. and Nygren, A. (2010), "Impacts of fair trade certification on coffee farmers, cooperatives, and laborers in Nicaragua", Agriculture and Human Values, Vol. 27 No. 3, pp. 321-333.

Varangis, P., Siegel, P.B., Giovannucci, D. and Lewin, B. (2003), Dealing with the Coffee Crisis in Central America: Impacts and Strategies, World Bank, Washington, DC, available at: www.wds.worldbank.org/servlet/WDSContentServer/WDSP/IB/2003/04/23/000094946_ 03040404262852/Rendered/PDF/multi0page.pdf (accessed May 1, 2012).

Webber, C.M. and Labaste, P. (2010), Building Competitiveness in Africa's Agriculture: A Guide to Value Chain Concepts and Applications, World Bank, Washington, DC, available at: https:// openknowledge.worldbank.org/bitstream/handle/10986/2401/524610PUB0AFR0101Official0 Use0Only1.pdf?sequence=1 (accessed June 12, 2013). 
JADEE

4,2

156
Wilson, B.R. (2010), "Indebted to fair trade? Coffee and crisis in Nicaragua", Geoforum, Vol. 41 No. 1, pp. 84-92.

World Bank (2007), World Development Report 2008: Agriculture for Development, World Bank, Washington, DC, available at: http://siteresources.worldbank.org/INTWDR2008/ Resources/WDR_00_book.pdf (accessed March 19, 2013).

World Bank (2012), Global Development Finance, available at: http://data.worldbank.org/datacatalog/global-development-finance (accessed August 2, 2012).

World Bank (2013), Producer Organizations, available at: http://web.worldbank.org/WBSITE/ EXTERNAL/TOPICS/EXTARD/0, contentMDK:20450986 isCURL:Y menuPK:1308455 pagePK:148956 piPK:216618 theSitePK:336682,00.html (accessed May 2, 2013).

\section{About the authors}

Dr Nigel Poole initially trained in agricultural sciences and agricultural extension before completing his $\mathrm{PhD}$ at the Wye College, University of London. He has lived and worked in southern Africa and South America and conducted research in many other regions. Currently he works at the Centre for Development, Environment and Policy, SOAS, University of London. Dr Nigel Poole is the corresponding author and can be contacted at: np10@soas.ac.uk

Dr Jason Donovan, after undergraduate and postgraduate studies in the USA, Jason Donovan worked for many years at the Tropical Agricultural Research and Higher Education Center (CATIE), Costa Rica, principally teaching and conducting research in Latin America and the Caribbean Basin. He completed his $\mathrm{PhD}$ at the SOAS, University of London, and currently works for the World Agroforestry Centre, Lima, Peru.

To purchase reprints of this article please e-mail: reprints@emeraldinsight.com Or visit our web site for further details: www.emeraldinsight.com/reprints 